\title{
Behavioral, thermoregulatory, and operational aspects of shallow pool pens used in gilts production
}

\section{Aspectos comportamentais, temorregulatórios e operacionais do uso de lâmina d'água rasa na criação de leitoas}

\author{
Heverton Michael Biazzi ${ }^{1}$; Diovani Paiano ${ }^{2 *}$; Maria Luisa Appendino Nunes ${ }^{3}$; \\ Marcelise Regina Fachinello ${ }^{4}$; Pedro Filipe de Souza Teles ${ }^{5}$
}

\begin{abstract}
This work was conducted to assess behavioral, thermoregulatory and operational aspects of gilt breeding (Body weight, 25-110 kg) whilst the animals were housed in 2-cm deep shallow pool pens (SPP), without the addition of water, compared to the use of fully compact floor pens (TSF) during the winter and summer seasons. Commercial female strains for high lean tissue accretion were used, housed in grower/finisher pens for 108 days (11 animals/pen, $1.2 \mathrm{~m}^{2} /$ animal). Instantaneous observations of behavior were carried out every 12 min between 7:00 and 19:00 hours throughout the six days of the raising period. At the end of the raising period, the operational aspects of cleaning the facilities were analyzed. A $2 \times 2$ factorial scheme design was used, with two types of floors and two seasons, with three replicates. The average temperatures in winter and summer were $19.9 \pm 2.2^{\circ} \mathrm{C}$ and $24.5 \pm 2.3^{\circ} \mathrm{C}$, respectively. The use of SPP reduced aggressive behavior and increased exploratory behavior, increased the time for the daily cleaning, and reduced the time for the final cleaning of the pens.
\end{abstract}

Key words: Animal welfare, environmental enrichment, facilities, pigs

\section{Resumo}

Foi conduzido um trabalho para avaliar os comportamentos, a termorregulação e os aspectos operacionais da criação de leitoas ( 25 aos $110 \mathrm{~kg}$ de peso vivo) alojadas em lâminas d'água rasa (LDR), com $2 \mathrm{~cm}$ de profundidade, sem adição de água em comparação com o piso totalmente compacto (PTC), nas estações de inverno e verão. Foram utilizadas fêmeas de linhagem comercial para alta deposição de tecido magro, alojadas em baias de crescimento/terminação por 108 dias (11 animais por baia, 1,2 $\mathrm{m}^{2}$ /animal). Foram realizadas observações instantâneas do comportamento, a cada 12 minutos, das 7 h00min às $19 \mathrm{~h} 00$ min por seis dias ao longo do período de criação. No final do período de criação foram analisados os aspectos operacionais da limpeza das instalações. Foi utilizado delineamento em um esquema fatorial $2 \times 2$, com dois tipos de pisos e duas estações, com três repetições. As temperaturas médias do ar no inverno e verão foram de $19,9 \pm 2,2^{\circ} \mathrm{C}$ e $24,5 \pm 2,3^{\circ} \mathrm{C}$, respectivamente. A utilização de LDR reduziu os comportamentos agressivos e aumentou os comportamentos exploratórios, aumentou o tempo de limpeza diário e reduziu o tempo de limpeza final das baias.

Palavras-chave: Bem-estar animal, enriquecimento ambiental, instalações, suínos

${ }^{1}$ Zootecnista, Poli-Nutri Nutrição Animal, Treze Tilia, SC, Brasil. E-mail: heverton.biazzi@hotmail.com

2 Prof.do Dept ${ }^{\circ}$ de Zootecnia, Universidade do Estado de Santa Catarina, UDESC, Chapecó, SC, Brasil. E-mail: diovani@hotmail.com

3 Prof a do DZO/UDESC, Chapecó, SC, Brasil. E-mail: maria.anunes@udesc.br

${ }^{4}$ Zootecnista, Discente do Curso de Doutorado, do Programa de Pós-Graduação em Zootecnia da Universidade Estadual de Maringá, UEM, Maringá, PR. Brasil. E-mail: lise_faqui@hotmail.com

${ }^{5}$ Zootecnista, Discente do Curso de Medicina Veterinária, UDESC/CAV, Lages, SC, Brasil. E-mail: pedroteles@zootecnista.com.br

* Auhtor for correspondence 


\section{Introduction}

There is an increasing pressure on industrial pig farms, especially in the southern states of Brazil, for production systems to incorporate a higher degree of animal welfare and to have a low environmental impact (MOLENTO, 2005). In this context, the use of low cost, easy deployment systems, which do not increase the waste problems associated with pig production, are essential.

The domestic pig (Sus scrofa domesticus) has a poorly developed thermoregulatory mechanism and adult pigs are very sensitive to heat. Therefore, climatic conditions are one of the main limiting factors in the productive efficiency of the swine industry, especially when the temperature is above their thermal comfort zone (RENAUDEAU et al., 2013). The use of technologies that minimize heat stress is necessary to improve the efficiency of animal feeding. Taking this into account, the use of shallow pool pens has been shown to improve the performance of pigs during the growth phase (REIS, 1995; MOREIRA et al., 2003) and to reduce hostile behaviors, such as aggression and stereotypies (PAIANO et al., 2007).

The shallow pool pen system, used in pig farming, involves the use of surface stream water, 5-10 cm deep, located at the back of the pens (MOREIRA et al., 2003; NAGAE; DAMASCENO; RICHARD, 2005), which aims to increase the heat loss of pigs through the process of conduction and convection. The use of this system provides a more natural environment for swine, especially because it promotes wallowing, an important behavioral pattern in the thermoregulatory processes of this specie (BRACKE, 2011).

Pig production systems should also be analyzed for their environmental impacts (PALHARES; CALIJURI, 2007). Therefore, the traditional system of pool pens is considered critical to the environment, mainly due to the increased dilution of the waste, which complicates its management and treatment.
Due to the increased dilution of waste, the prevailing recommendation is to not use the pool pen in pig farming; however, there is a system commonly used in Western Santa Catarina, where a water depth of $\sim 2 \mathrm{~cm}$ is used without the necessity to constantly replenishes water, which captures the waste drinking water and liquid waste. Although it has not yet been investigated, the shallow pool pen system (SPP) could be used as an alternative to improve the environment and pigs welfare during raising phase, with environmental advantages compared to the conventional pool pen system.

Therefore, the present study was conducted to evaluate the behavior of gilts and the operational aspects of their production in SPP, during winter and summer in Midwestern Santa Catarina.

\section{Material and Methods}

The study was conducted in a commercial unit of finishing pigs, located in the Midwest of Santa Catarina $\left(27^{\circ} 01^{\prime} \mathrm{S}, 51^{\circ} 48^{\prime} \mathrm{O}\right)$, at an altitude of 970 $\mathrm{m}$. The climate in this region is classified as humid mesothermal subtropical with hot summers, with an annual average temperature of $17-18^{\circ} \mathrm{C}$ and average relative humidity between 76 and $80 \%$ (PANDOLFO et al., 2002).

The gilts were housed in a grower/finisher facility, east-west oriented, open laterally, with a ceiling height of $3.0 \mathrm{~m}$ consisting of a canvas lining covered with clay tiles. Pens $(4.1 \times 3.20 \mathrm{~m})$ had a concrete floor at $3 \%$ of slope, with feeders along the front of the stall, a drinking cups at the back with a flow of $1.91 \mathrm{~L} / \mathrm{min}$, and a $1.3 \mathrm{~m}$ wide corridor. In the SPP, the pools occupied $2.50 \mathrm{~m}^{2}$ of the pens (approximately 20\% of the floor) with a height of $1.5-2.0 \mathrm{~cm}$. All pens were cleaned daily by scraping, and the removal of the accumulated dust on the floors was carried out weekly.

Six pens with compact concrete floor were used for the assessments, where three pens were adapted to accumulate wastewater from the drinker cups and the liquid waste, determined as the shallow pool 
pens (SPP), and three pens had only the compact concrete floor (TSF), i.e., without water-blade. This arrangement allowed that the two treatments were investigated simultaneously. Eleven gilts/pen were housed (a total of 132 animals, housed during the two seasons) with $1.2 \mathrm{~m}^{2} /$ gilt, with a linear area of $0.3 \mathrm{~m}$ of feeder/animal. The housed gilts weighed from 25 to $110 \mathrm{~kg}$ of body weight (accommodation, 108 days). Behavioral variables were assessed over six periods, and operational evaluations over five periods during the experiment.

The animals were distributed according to a complete factorial design with two floorings (SPP and TSF) and two seasons (winter and summer), resulting in four treatments with three replicates. The pens formed the experimental units. For behavioral assessments, five animals were randomly selected per pen, which were identified dorsally with a nontoxic marker, two days before the beginning of the evaluations.

Surface temperatures were recorded with an infrared thermometer with fixed emissivity of 0.95 . The back temperatures were recorded every hour, in three animals per pen, during behavior evaluations, and floor temperatures were assessed every hour. Environmental variables were recorded with an automatic thermohygrometer (accuracy of $\pm 3 \%$ for relative humidity and $\pm 1{ }^{\circ} \mathrm{C}$ for air temperature), with sampling intervals of $10 \mathrm{~min}$, positioned at the geometric center of the facility. The values obtained were used to calculate the temperature-humidity index (THI) (THOM, 1959).

Six pelleted rations were provided during the raising phase (Table 1), given in four daily rations of $30 \mathrm{~min}$, starting at the following times: 7:00, 10:30, 14:30 and 18:30 hours, according to the farm routine. Water was supplied ad libitum, and the animals were not handled during the night.

Table 1. Calculated chemical composition and approximate feed consumption in the raising period.

\begin{tabular}{lcccccc}
\hline Itens & $\mathrm{R} 1$ & $\mathrm{R} 2$ & $\mathrm{R} 3$ & $\mathrm{R} 4$ & $\mathrm{R} 5$ & $\mathrm{R} 6$ \\
\hline Crude protein, \% & 17,0 & 18,0 & 16,0 & 16,0 & 15,0 & 18,0 \\
Crude fat, \% & 5,0 & 4,0 & 3,5 & 2,0 & 3,5 & 3,0 \\
Crude fiber, \% & 5,0 & 5,0 & 4,0 & 6,0 & 4,0 & 4,5 \\
Ash, \% & 7,0 & 5,0 & 4,5 & 7,0 & 4,0 & 5,5 \\
Ca (min.), \% & 1,0 & 0,8 & 0,75 & 0,9 & 0,7 & 0,8 \\
P (máx.), \% & 0,6 & 0,5 & 0,45 & 0,9 & 0,4 & 0,5 \\
Ractopamine, mg/kg & 0,0 & 0,0 & 0,0 & 0,0 & 0,0 & 5,0 \\
Feed consumption per gilt, $\mathrm{kg}$ & 25,0 & 15,0 & 30,0 & 90,0 & 25,0 & 65,0 \\
\hline
\end{tabular}

Source: Elaboration of the authors.

During this study, observations were carried out during the day (7:00-19:00 h), with a sampling interval of $12 \mathrm{~min}$ (five observations per hour), with instantaneous recording of behavior, according to the methodology described by Martin and Baterson (1986).

Behaviors variables were divided into the following groups: Eating (ET); Drinking water (DW); Standing - Standing, sitting, or walking
(SSW); Exploring the pens (EXP); Sleeping in the back of the pens - animal lying or sleeping on the shallow pool part of the pen (SLB); Sleeping in the front of the pens - animal lying or sleeping on the dry part of the pen (SLF); Excreting in the back of the pens - defecating and urinating in the shallow pool part of the pens (EXB); Excreting in front of the pens - defecating and urinating in the front of the pens (EXF); Hostility-aggressive interaction (HOS); 
Fighting for drinkers cup (FIG); Belly nosing (BN); Mounting other animals (MON) according to a work ethogram proposed by Paiano et al. (2007).

To determine the operational aspects of SPP use, the time taken to complete the daily dry pen cleaning (cleaning by scraping) was recorded. At the end of the experimental period, after the removal of all animals, the time required to clean the pens, as well as the volume of water used, and the accumulation of organic material stacked in the pen were recorded. The amount of dust accumulated on the pens floor was weighed weekly.

The behavioral variables and surface temperatures (floor and dorsum) were analyzed, according to a factorial designs $(2 \times 2)$ with two systems (TSF and SPP) and two seasons (summer and winter). The SAS (2008) computer program was used with the GENMOD procedure, in which it was assumed that the behavioral variables had a Poisson distribution. Environmental and operational variables were analyzed assuming a normal distribution and the means were compared using Duncan's multiple range test ( $5 \%$ probability).

\section{Results and Discussion}

Dry bulb temperatures within the facility were lower $(P<0.05)$ during winter at $19.9 \pm 2.2^{\circ} \mathrm{C}$, compared to the summer in which the average temperature was $24.5 \pm 2.3^{\circ} \mathrm{C}$. Similar differences were observed for relative humidity and THI. The relative humidity was $67.5 \% \pm 7.9$ and $74.89 \pm$ $8.9 \%$, and THI values were $66.3 \pm 2.8$ and 73.1 \pm 3.5 in winter and summer, respectively. The different averages of the environmental variables (Figure 1) are indicative of seasonal environmental patterns.

Figure 1. Means of climatic variables recorded during the study period at different times of the day. W=winter and $\mathrm{S}$ $=$ summer. $\mathrm{DBT}=$ dry bulb temperature; $\mathrm{THI}=$ temperature-humidity index and $\mathrm{RH}=$ relative humidity.

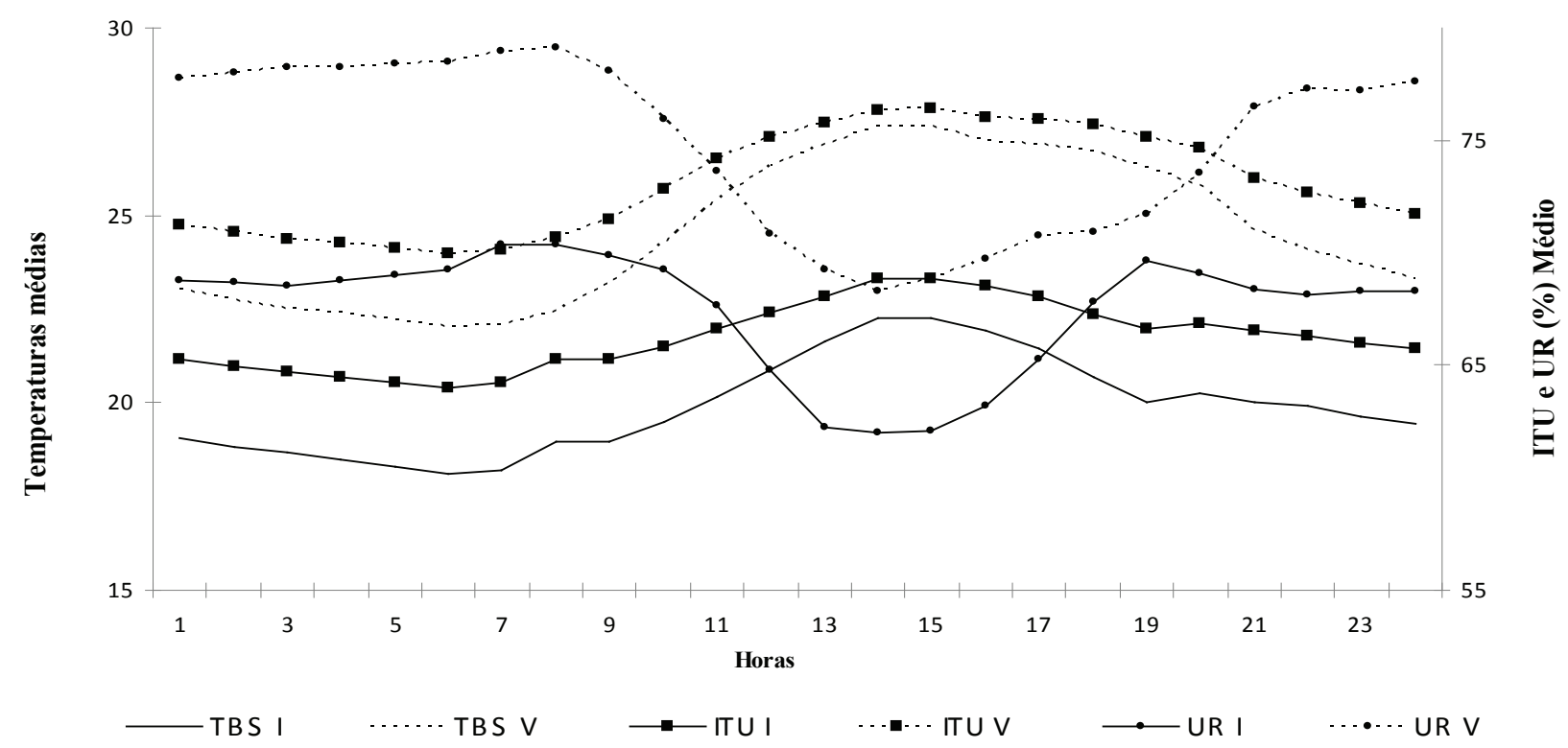

Source: Elaboration of the authors. 
The temperature range required for the thermal comfort of growing-finishing pigs is $12-21{ }^{\circ} \mathrm{C}$, with relative humidity between 65 and $75 \%$ (VEIT; TROUTT, 1982). Therefore, in this study, the animals were under heat stress in the summer at 14:00, 15:00, and 16:00 hours (Figure 1). In the summer, temperatures exceeded $27^{\circ} \mathrm{C}$, wich is considered a critical limit for pigs (SAMPAIO et al., 2004). Similarly, during the same time, the THI exceeded 75 points. Silva (2000) considered critical THI values below 55 (cold stress) and above 71 (heat stress), which indicate that in the summer, THI values especially in the afternoon, were above those considered optimal for this species.

The mean floor temperature inside the pen and the back temperatures of the animals (Table 2) did not differ between treatments or seasons $(P>0.05)$. However, the variable floor temperature in front of the pen differed between seasons $(P<0.05)$, with a higher temperature measured during the summer. It is possible that the high specific heat of water limits the floor temperature variability in the pen, where the waste flow area of the pen was located. In front of the pen, as there was no standing water, this phenomenon was not observed, and therefore, higher floor temperatures were recorded in summer.

Table 2. Average temperature of the floor surface pens, in the front (T.S. Front) and back of the pens (T.S. Back) and dorsal temperatures of pigs (T. Dorsal) in SPP and TSF treatments, in winter and summer.

\begin{tabular}{|c|c|c|c|c|c|c|c|c|c|c|c|}
\hline \multirow{3}{*}{ Variables, ${ }^{\circ} \mathrm{C}$} & \multicolumn{5}{|c|}{ Treatments } & \multirow{2}{*}{\multicolumn{2}{|c|}{ Floor }} & \multirow{3}{*}{$\mathrm{P}=$} & \multirow{2}{*}{\multicolumn{2}{|c|}{ Season }} & \multirow{3}{*}{$\mathrm{P}=$} \\
\hline & \multicolumn{2}{|c|}{ SPP } & \multicolumn{2}{|c|}{ TSF } & \multirow{2}{*}{$\begin{array}{c}\mathrm{F}^{*} \mathrm{~S} \\
\mathrm{P}=\end{array}$} & & & & & & \\
\hline & Winter & Summer & Winter & Summer & & SPP & TSF & & Winter & Summer & \\
\hline T. Dorsal & 37,1 & 36,8 & 36,8 & 36,6 & ns & 37,0 & 36,6 & ns & 37,0 & 36,7 & $\mathrm{~ns}$ \\
\hline T. S. Back & 25,0 & 25,8 & 28,5 & 28,6 & ns & 25,4 & 28,6 & ns & 26,7 & 27,2 & ns \\
\hline T. S. Front & 19,4 & 24,5 & 19,7 & 25,7 & ns & 22,0 & 22,7 & ns & 19,6 & 25,1 & 0,01 \\
\hline
\end{tabular}

$\mathrm{F} * \mathrm{~S}-$ Interaction between floor and season.

Source: Elaboration of the authors.

Skin temperature can be an indicator of physiological heat stress in pigs (ANDERSEN et al., 2008; RENAUDEAU et al., 2010), since peripheral circulation is a form of heat dissipation. However, the dorsal surface temperature of the animal was not affected by the presence of shallow waters (Table 2), although the critical heat period occurred during the summer.

There was an association $(P<0.05)$ between drinking behavior and fighting for drinkers, with higher TSF values recorded during the summer (Table 3). This may indicate that the shallow pool system favored thermal equilibrium, diminishing the need for water intake. Increased water consumption is one of the main indicators of heat stress in pigs during the finishing phase (HUYNH et al., 2005), because it permits cooling favoring homeothermy.

In winter, standing and exploring behaviors were more frequent $(P<0.05)$ and sleeping behavior was less frequent $(P<0.05)$. Besides body weight, ambient temperature has a substantial effect on the posture (lying and or standing) adopted by pigs (SAVARY et al., 2009), so that pigs in thermal comfort adopt an increased frequency of behaviors that involve energy expenditure (PAIANO et al., 2007). As the temperature increases, pigs use behavioral, physical, and chemical mechanisms to adjust their body temperature, which may lead to deviations in energy available for production, and a change in the nutritional requirement of the animal (MANNO et al. 2005). 
There was an interaction $(\mathrm{P}<0.05)$ between season and kind of floor for sleeping behavior at the back of the pen, and was more frequent in the TSF treatment only in summer, without differences in winter $(\mathrm{P}>0.05)$. The sleeping behavior at the back of the pen indicates that the animals are seeking a damp location in which to lie. In environments that induce heat stress, pigs employ a strategy of dampening their body surface to promote thermoregulation (BARBARI; CONTI, 2009; BRACKE, 2011).

This can also be achieved by seeking dirty regions of the pens, where they can moisten their body surface with feces and urine (HUYNH et al., 2007), which may explain the higher values of this variable during the TSF treatment in the summer.

Therefore, SPP and conventional water pools may be alternatives to increase heat loss (REIS, 1995; MOREIRA et al., 2003; PAIANO et al., 2007).

There was no difference $(P>0.05)$ among pigs excreting at the back of the pen. However, there was an interaction $(P<0.05)$ between kind floor and season for pigs excreting in front of the pen, with a greater value for TSF in the summer, probably reflecting the increased water consumption, indicating that SPP may favor hygienic behavior of pigs. Moreira et al. (2003) observed less waste in shallow water pens when compared to partially slatted floor pens. Similarly, Huynh et al. (2006) found that growing pigs excrete less in the rest area in pens with shallow pools, when compared to pens with sprinklers and without any air conditioning.
Patterns of defecation and urination by pigs are directly related to the temperature and the environment. In an experiment where pigs were confined to temperatures below $23^{\circ} \mathrm{C}$, defecation was restricted to the drainage areas of the pen. With an increase in temperature, the animals increasingly used the compact areas of the pen for defecation (AARNINK et al. 2006).

There was a higher frequency $(P<0.05)$ of hostility in the summer, particularly in TSF pens; the higher aggressiveness may have occurred because of the discomfort resulting from heat stress. The lower hostility observed with SPP is similar to that reported by Paiano et al. (2007), probably due to the greater welfare of these animals, suggesting that SPP may have favored the pigs' comfort. The use of environmental enrichment in pig breeding pens may reduce the aggressive behavior of animals (VAN DE WEERD; DAY, 2009). In this regard, the use of SPP, as well as deep bedding, could be used as a form of environmental enrichment with the aim of reducing agonistic behavior.

There was a higher frequency $(\mathrm{P}<0.05)$ of Belly nosing in summer, however, there was not interaction and effects of floor type $(\mathrm{P}>0.05)$. Belly nosing is considered an abnormal behavior observed more frequently in pigs subjected to early weaning, being a repetitive frustrationinduced motion (LATHAM; MASON, 2008). The increased frequency of this behavior in the summer suggests that heat stress may have been contributing factor. 


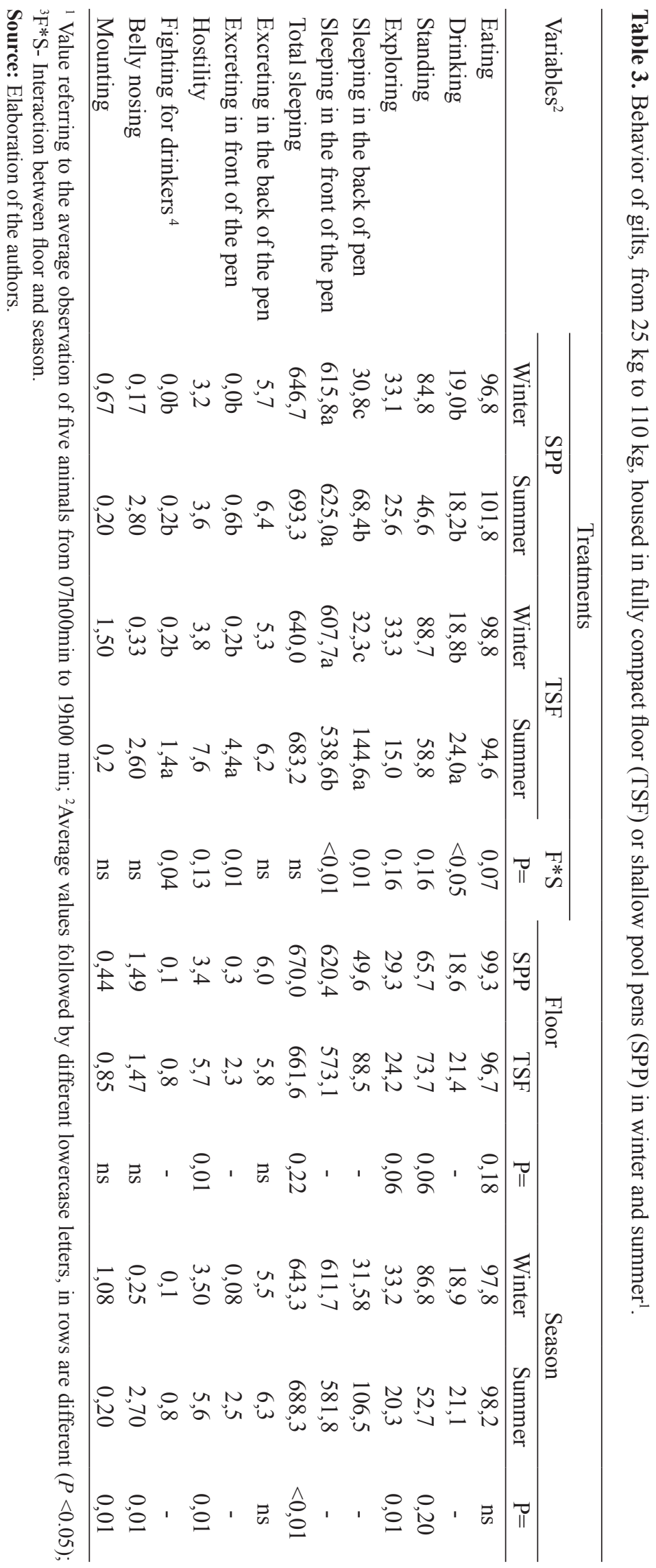


The duration of daily cleaning by pigs (Table 4) was higher $(P<0.05)$ in pigs in the SPP treatment, possibly due to the volume of water that accumulated throughout the day, which was discarded at every cleaning by scraping. The duration of daily cleaning was higher $(P<0.05)$ in summer, probably due to increased water consumption by the pigs, which led to increased production of liquid waste.

Table 4. Operational variables of gilt breeding from $25 \mathrm{~kg}$ to $110 \mathrm{~kg}$, housed in different seasons (winter and summer) and on different floors (shallow water pen and traditional compact floor) ${ }^{1}$.

\begin{tabular}{|c|c|c|c|c|c|c|c|c|c|c|c|}
\hline \multirow{3}{*}{ Variables } & \multicolumn{5}{|c|}{ Treatments } & \multirow{2}{*}{\multicolumn{2}{|c|}{ Floor }} & \multirow{3}{*}{$\mathrm{P}=$} & \multirow{2}{*}{\multicolumn{2}{|c|}{ Season }} & \multirow{3}{*}{$\mathrm{P}=$} \\
\hline & \multicolumn{2}{|c|}{ SPP } & \multicolumn{2}{|c|}{ TSF } & \multirow{2}{*}{$\begin{array}{c}\mathrm{F}^{*} \mathrm{~S} \\
\mathrm{P}=\end{array}$} & & & & & & \\
\hline & Winter & Summer & Winter & Summer & & SPP & TSF & & Winter & Summer & \\
\hline D.C.T. ${ }^{2}$ & 1,40 & 1,57 & 0,81 & 1,14 & Ns & 1,49 & 0,98 & 0,01 & 1,06 & 1,36 & 0,01 \\
\hline W.A.D. ${ }^{3}$ & $0,12 b$ & $0,32 b$ & $1,68 \mathrm{a}$ & $0,54 b$ & 0,01 & 0,22 & 1,11 & - & 0,97 & 0,43 & - \\
\hline A.O.M. ${ }^{4}$ & 3,20 & 16,17 & 8,82 & 23,02 & Ns & 9,69 & 15,92 & 0,01 & 9,31 & 19,60 & 0,01 \\
\hline W.F.C. ${ }^{5}$ & $87,8 b$ & $104,3 b$ & $85,3 b$ & $145,6 a$ & 0,02 & 96,1 & 115,5 & - & 96,20 & 124,9 & - \\
\hline T.L.F ${ }^{6}$ & 22,67 & 28,20 & 24,40 & 48,12 & 0,09 & 25,43 & 36,26 & 0,05 & 27,78 & 38,16 & 0,02 \\
\hline
\end{tabular}

${ }^{1}$ Means followed by different lowercase letters in the row differ $(P<0.05)$ by the Duncan's multiple range test. ${ }^{2}$ D.C.T. - daily cleaning time (min); ${ }^{3}$ W.A.D. - Weekly Accumulation of dust (kg); ${ }^{4}$ A.O.M. - Accumulated organic matter (kg); ${ }^{5}$ W.F.C. - use of water for final cleaning (L); ${ }^{6}$ T.L.F - final cleaning time (min).

Source: Elaboration of the authors.

There was interaction $(P<0.05)$ between season and flooring type for the weekly accumulation of dust, with higher dust accumulating on the TSF flooring and in winter, at about $128 \mathrm{~g} / \mathrm{m}^{2}$ dust per week. The reduction in accumulated dust is an essential air quality factor in pig facilities. The reduction of dust in the pens, as well as gases in the facilities, are health determinants of the porcine respiratory system, as low-quality air causes direct toxic effects on ciliated cells impairing the mucociliary defense mechanism (BARCELLOS et al., 2008). Therefore, the presence of shallow waters and the associated daily cleaning of stall floors can be used to reduce the amount of accumulated dust. This will consequently improve the pig-breeding environment, reducing the accumulation of dust and stacked feces on the floors.

Similarly, there was interaction $(P<0.05)$ between the use of water for cleaning, and the highest value obtained for TSF flooring in summer, caused by a greater dehydration of manure in the stalls without the shallow water, and consequently increased the use of water for the organic material removal. In pens with TSF there was a higher $(P<0.05)$ amount of stacked organic material compared to SPP pens, which led to an increased $(P<0.05)$ time taken for the final cleaning of pens.

The use of shallow water reduced agonistic behavior, competition for drinkers, a reduction in dirt and dust as well as water usage and time for final cleaning. However, the length of daily cleaning increased. Therefore, further studies should be conducted to evaluate economic variables related to breeding in shallow water pens, as well as potential variables related to the characteristics of the carcass.

Although the use of shallow pool pens provided better animal welfare conditions, especially when behavioral aspects such as the lower incidence of aggression and fighting for drinkers were analyzed. The use of shallow water increased the daily cleaning time, it led to lower concentrations of dust and reduced the time taken for the final cleaning of the pens. 


\section{References}

AARNINK, A. J. A.; SCHRAMA, J. W.; HEETKAMP, M. J. W.; STEFANOWSKA, J.; HUYNH. T. T. T. Temperature and body weight affect fouling of pig pens. Journal of animal Science, Champaign, v. 84, n. 8, p. 2224-2231, 2006.

ANDERSEN, H. M. L.; JØRGENSEN, E.; DYBKJÆR, L.; JØRGENSEN, B. The ear skin temperature as an indicator of the thermal comfort of pigs. Applied Animal Behaviour Science, Amsterdam, v. 113, n. 1, p. 43-56, 2008.

BARBARI, M.; CONTI, L. Use of different cooling systems by pregnant sows in experimental pen. Biosystems Engineering, Cambridge, v. 103, n. 2, p. 239244, 2009.

BARCELLOS, D. E. S. N.; BOROWSKI, S. M.; GHELLER, N. B.; SANTI, M.; MORES, T. J. Relação entre ambiente, manejo e doenças respiratórias em suínos. Acta Scientiae Veterinariae, Porto Alegre, v. 36, n. 1, p. 87-93, 2008.

BRACKE, M. B. M. Review of wallowing in pigs: description of the behaviour and its motivational basis. Applied Animal Behaviour Science, Amsterdam, v. 132, n. 1-2, p. 1-13, 2011.

HUYNH, T. T. T.; AARNINK, A. J. A.; HEETKAMP, M. J. W.; VERSTEGEN, M. W. A.; KEMP, B. Evaporative heat loss from group-housed growing pigs at high ambient temperatures. Journal of Thermal Biology, Oxford, v. 32, n. 5, p. 293-299, 2007.

HUYNH, T. T.; AARNINK, A. J.; VERSTEGEN, M. W.; GERRITS, W. J.; HEETKAMP, M. J.; KEMP, B.; CANH, T. T. Effects of increasing temperatures on physiological changes in pigs at different relative humidities. Journal of Animal Science, Champaign, v. 83, n. 6, p. 1385-1396, 2005.

HUYNH, T. T. T.; AARNINK, A. J. A.; TRUONG, C. T.; KEMP, B.; VERSTEGEN, M. W. A. Effects of tropical climate and water cooling methods on growing pigs' responses. Livestock science, Maryland Heights, v. 104, n. 3, p. 278-291, 2006.

LATHAM, N. R.; MASON, G. J. Maternal deprivation and the development of stereotypic behavior. Applied Animal Behaviour Science, Amsterdam, v. 110, n. 1, p. 84-108, 2008.

MANNO, M. C.; OLIVEIRA, R. F. M.; DONZELE, J. L.; FERREIRA, A. S.; OLIVEIRA, W. P.; LIMA, K. R. S.; VAZ, R. G. M. V. Efeito da temperatura ambiente sobre o desempenho de suínos dos 15 aos $30 \mathrm{~kg}$. Revista Brasileira Zootecnia, Viçosa, v. 34, n. 6, p. 1963-1970, 2005.
MARTIN, P.; BATERSON, P. Measuring behavior: an introductory guide. Cambridge: Cambridge University Press, 1986. 2000 p.

MOLENTO, C. F. M. Bem-estar e produção animal: aspectos econômicos - revisão. Archives of Veterinary Science, Curitiba, v. 10, n. 1, p. 111, 2005.

MOREIRA, I.; PAIANO, D.; OLIVEIRA, G. C.; GONÇALVES, G. S.; NEVES, C. A.; BARBOSA, O. R. Desempenho e características de carcaça de suínos (33$84 \mathrm{~kg}$ ) criados em baias de piso compacto ou com lâmina d'água. Revista Brasileira de Zootecnia, Viçosa, v. 32, n. 1, p. 132-139, 2003.

NAGAE, R.; DAMASCENO, S.; RICHARD, A. Caracterização do dejeto de suínos em crescimento e terminação criados no sistema de lâmina d'água submetido a dois manejos de higienização. In: CONGRESSO BRASILEIRO DE ENGENHARIA SANITÁRIA E AMBIENTAL, 2005, Campo Grande. Anais... Campo Grande: ABES, Associação Brasileira de Engenharia Sanitária e Ambiental, 2005. p. 18-23.

PAIANO, D.; BARBOSA, O. R.; MOREIRA, I.; QUADROS, A. R. B.; SILVA, M. A. A.; OLIVEIRA, C. A. L. Comportamento de suínos alojados em baias de piso parcialmente ripado ou com lâmina d'água. Acta Scientiarum. Animal Sciences, Maringá, v. 29, n. 3, p. 345-351, 2007.

PALHARES, J. C. P.; CALIJURI, M. C. Caracterização dos afluentes e efluentes suinícolas em sistemas de crescimento/terminação e qualificação de seu impacto ambiental. Ciência Rural, Santa Maria, v. 37, n. 2, p. 502-509, 2007.

PANDOLFO, C.; BRAGA, H. J.; SILVA, J. R. V. P.; MASSIGNAM, A. M.; PEREIRA, E. S.; THOMÉ, V. M. R.; VALCI, F. V. Atlas climatológico digital do Estado de Santa Catarina. Florianópolis: EPAGRI, 2002. CDROM.

REIS, R. L. S. P. Efeito da lâmina d'água no crescimento e na terminação de suínos. 1995. Dissertação (Mestrado em Engenharia Agrícola) - Faculdade de Engenharia Agrícola. Universidade Estadual de Campinas, Campinas.

RENAUDEAU, D.; FRANCES, G.; DUBOIS, S.; GILBERT, H.; NOBLET, J. Effect of thermal heat stress on energy utilization in two lines of pigs divergently selected for residual feed intake. Journal of Animal Science, Champaign, v. 91, n. 3, p. 1162-1175, 2013.

RENAUDEAU, D.; ANAIS, C.; TEL, L.; GOURDINE, J. L. Effect of temperature on thermal acclimation in growing pigs estimated using a nonlinear function. Journal of Animal Science, Champaign, v. 88, n. 11, p. 3715-3724, 2010. 
SAMPAIO, C. A. P.; PAIVA, C. A.; CRISTANI, J.; DUBIELA, J. A.; BOFF, C. E.; OLIVEIRA, M. A. Avaliação do ambiente térmico em instalação para crescimento e terminação de suínos utilizando os índices de conforto térmico nas condições tropicais. Ciência Rural, Santa Maria, v. 34, n. 3, p. 785-790, 2004.

SAVARY, P.; GYGAX, L.; WECHSLER, B.; HAUSER, $R$. Effect of a synthetic plate in the lying area on lying behaviour, degree of fouling and skin lesions at the leg joints of finishing pigs. Applied Animal Behaviour Science, Amsterdam, v. 118, n. 1, p. 20-27, 2009.

SILVA, G. R. Introdução à bioclimatologia animal. São Paulo: Nobel, 2000. 286 p.
STATISTICAL ANALYSIS SYSTEM INSTITUTE SAS. SAS/STAT 9.2 User's guide. SAS Institute Inc, Cary, NC., 2008.

THOM, E. C. The discomfort index. Weatherwise, Washington, v. 12, n. 1, p. 57-56, 1959.

VAN DE WEERD, H. A.; DAY, J. E. A review of environmental enrichment for pigs housed in intensive housing systems. Applied Animal Behaviour Science, Amsterdam, v. 116, n. 1, p. 1-20, 2009.

VEIT, H. P.; TROUT, H. F. Monitoring air quality for livestock respiratory health. Veterinary Medicine and Small Animal Clinican, Amsterdam, v. 77, n. 1, p. 454463, 1982. 